Zeszyty Naukowe Szkoły Głównej Gospodarstwa Wiejskiego w Warszawie

Problemy Rolnictwa Światowego tom 18 (XXXIII), zeszyt 1, 2018: 309-318

DOI: 10.22630/PRS.2018.18.1.28

Barbara Wieliczko ${ }^{1}$

Instytut Ekonomiki Rolnictwa i Gospodarki Żywnościowej - Państwowy

Instytut Badawczy w Warszawie

\title{
System oceny wsparcia programów rozwoju obszarów wiejskich 2014-2020
}

\section{System of Evaluation of Rural Development Programmes 2014-2020}

\begin{abstract}
Synopsis. System oceny wsparcia jest ważnym elementem analizy oddziaływania interwencji publicznej na sytuację społeczno-gospodarczą. Dostarcza również wiedzy o koniecznych zmianach. W związku z tym powinien być jak najlepiej zaprojektowany i realizowany. W artykule przedstawiono unijny system oceny PROW 2014-2020 obowiązujący państwa członkowskie. Zastosowano ujęcie porównawcze i obecny system odniesiono do rozwiązań zastosowanych w poprzednim okresie programowania. Skoncentrowano się na wytycznych do oceny PROW stosowanych w obu badanych okresach programowania $\mathrm{i}$ ograniczono się do zasad oceny śródokresowej i końcowej. Celem artykułu jest odpowiedź na pytanie „Czy system oceny PROW 2014-2020 zapewnia większą wiedzę o efektach wsparcia w porównaniu z okresem programowania 2007-2013?". Wyniki analizy wskazują na to, że obecne rozwiązania nie zapewniają kompletnych i przejrzystych wyników pokazujących w pełni, jakie jest oddziaływanie interwencji na poziomie poszczególnych instrumentów.
\end{abstract}

Słowa kluczowe: system oceny, program rozwoju obszarów wiejskich, oddziaływanie wsparcia

\begin{abstract}
The evaluation system is an important part of the analysis of the impact of public intervention on socio-economic reality. It also provides knowledge about the necessity of changes. Therefore, it should be designed and implemented as carefully as possible. The paper presents the EU RDP 2014-2020 evaluation system the Member States. A comparative approach was applied and the current system was compared with the previous one. The focus was put on the EC's guidelines for the RDPs' evaluation in both of the study periods and it was limited to principles of mid-term and ex-post evaluations. The aim of the paper was to answer the question "Does the RDP 2014-2020 evaluation system provide more knowledge on the effects of support compared to the 2007-2013 programming period?". The results of the analysis indicate that the current solutions do not provide complete and transparent results indicating the impact of intervention at the level of individual policy instruments.
\end{abstract}

Key words: evaluation system, rural development programme, impact of public support

JEL Classification: Q18, O20.

\section{Wprowadzenie}

Polityka rozwoju obszarów wiejskich Unii Europejskiej (UE) jest ważnym elementem Wspólnej Polityki Rolnej (WPR). W związku z koniecznością pokazania europejskiej wartości dodanej², która ma legitymizować unijne wydatki, próbuje się dokładniej oszacować skalę oddziaływania unijnego wsparcia na obszary nim objęte.

${ }^{1}$ dr, IERiGŻ-PIB, ul. Świętokrzyska 20, 00-002 Warszawa, e-mail: Barbara.Wieliczko@ierigz.waw.pl; https://orcid.org/0000-0003-3770-0409

${ }^{2}$ Europejska wartość dodana to pojęcie słabo zdefiniowane. Wskazuje na efekty wynikające z zastosowania polityki unijnej. Pojęcie to w odniesieniu do WPR zostało szeroko omówione m.in. w publikacji Gorzelak i in., 2017. 
Ewaluacja polityki stała się samodzielną subdyscypliną w ramach nauk społecznych (Esposti, Sotte, 2013). Ocena polityki stała się również integralnym elementem programów wsparcia współfinansowanych ze środków UE. Zakres i metody wykorzystywane do oceny determinują przyszłą wiedzę o rezultatach interwencji publicznej oraz o ich oddziaływaniu na gospodarkę. Ocena polityki rozwoju obszarów wiejskich UE jest szczególnie złożonym procesem z uwagi na różnorodność instrumentów stosowanych $\mathrm{w}$ ramach programów rozwoju obszarów wiejskich. Trudność sprawia też to, iż poszczególne instrumenty mają wielorakie cele, które często nie są w pełni przedstawione przez projektujących programy rozwoju obszarów wiejskich (Wakeford, 2010).

W artykule przedstawiono unijny system oceny programów rozwoju obszarów wiejskich 2014-2020 (PROW 2014-2020). Zastosowano ujęcie porównawcze i obecny system odniesiono do rozwiązań zastosowanych w poprzednim okresie programowania. Skoncentrowano się na wytycznych UE do oceny PROW zastosowanych w obu badanych okresach programowania i ograniczono się do zasad oceny śródokresowej i końcowej. Celem artykułu jest odpowiedź na pytanie „Czy system oceny PROW 20142020 zapewnia większą wiedze o efektach wsparcia w porównaniu z okresem programowania 2007-2013?". Odpowiedź na to pytanie pozwoli określić kierunki ewentualnych dalszych zmian w systemie oceny, które mogłyby zwiększyć jakość i kompleksowość oceny.

\section{Przegląd literatury}

Ewaluacja $^{3}$ to systematyczne badanie społeczno-ekonomiczne oceniające jakość i wartość programów publicznych (Olejniczak, 2007). Ewaluację przeprowadza się z użyciem zróżnicowanych metod i obejmuje ona zbieranie danych, analizę, ocenę oraz informowanie o wynikach. Celem ewaluacji jest oszacowanie (w odniesieniu do jasno sformułowanych kryteriów) jakości i wartości procesu oraz efektów wdrażania interwencji publicznych (Bienias i in., 2012). Jak wskazuje Wieliczko (2010), wyróżnia się cztery cechy odróżniające ewaluację od innych działań związanych z oceną, takich jak badania naukowe czy audyt. Obejmują one:

1) utylitaryzm - ewaluacja przygotowywana jest dla konkretnych odbiorców i ma za zadanie służyć poprawie jakości analogicznych interwencji;

2) łączenie empirii (badania zjawisk stanowiących konsekwencje realizacji programu) z normatywnym charakterem działania (ocena struktury i logiki działań);

3) interakcyjność procesu badania stanowiącego jednocześnie proces uczenia się;

4) ograniczona siła wpływu - brak formalnego obowiązku wdrożenia rekomendacji.

W przypadku ewaluacji służącej ocenie programów realizowanych ze środków UE mamy do czynienia z trzema typami całościowej oceny tych programów. Wyróżniamy następujące kategorie:

- ocena ex-ante - ocena realizowana przed przyjęciem programu przez KE. Ocena ta skoncentrowana jest na zgodności celów programu i wybranych do wdrażania instrumentów $\mathrm{z}$ potrzebami sektorów/obszarów objętych interwencją $\mathrm{w}$ ramach programu. Ocena ex-ante jest integralną częścią programów rozwoju obszarów wiejskich (Rozporządzenie nr 1698/2005; Rozporządzenie nr 1302/2013).

\footnotetext{
${ }^{3} \mathrm{~W}$ niniejszym artykule pojęcia „ocena” i ,ewaluacja” stosowane są zamiennie.
} 
- ocena śródokresowa - ocena w trakcie wdrażania programu skoncentrowana na analizie pierwszych rezultatów wdrażania mająca na celu określenie, czy niezbędne są jakieś zmiany w ukształtowaniu programu i jego poszczególnych instrumentów.

- ocena ex-post - ocena realizowana po zakończeniu wdrażania programu koncentrująca się na efektach bezpośrednich i pośrednich realizacji programu.

Kluczowym wyzwaniem dla procesu oceny interwencji wydaje się oddzielenie wpływu instrumentów polityki od innych czynników. Ewaluacja powinna uwzględnić i skwantyfikować relację interwencji z otoczeniem (Esposti, Sotte, 2013). Obecnie najpowszechniej wykorzystywanym i polecanym również przez Komisję Europejską (KE) (European..., 2016) sposobem oddzielenia wpływu wsparcia w ramach polityki rozwoju obszarów wiejskich od innych czynników wpływających na beneficjentów jest wykorzystanie metod kontrfaktycznych, takich jak metoda propensity score matching (PSM), czasami nazywana $\mathrm{w}$ polskiej literaturze przedmiotu metodą określającą statystyczny wpływ netto zmiennej niezależnej na zmienną zależną. W tym podejściu chodzi o zbadanie sytuacji beneficjentów wsparcia $\mathrm{w}$ porównaniu z sytuacją podmiotów zbliżonych, jeśli chodzi o cechy kluczowe dla wsparcia, które jednak nie były beneficjentami tego wsparcia. Problemem jest jednak często znalezienie odpowiednich podmiotów do takiej grupy kontrolnej.

Analizy systemów oceny polityki rozwoju obszarów wiejskich UE stosowanych w poprzednich okresach wskazywały na istotne niedoskonałości (Wieliczko, 2010; Midmore i in., 2008). Obecny okres programowania nie doczekał się jeszcze znaczących analiz systemu oceny. Jednak jak wskazują Prager i in. (2015), nadal w podejściu do ewaluacji niewystarczająco dużo uwagi poświęcono samemu podejściu do oceny polityki wiejskiej, a zwłaszcza jej instrumentów związanych $\mathrm{z}$ dążeniem do większego zaangażowania lokalnych społeczności, jak oddolne podejście LEADER. W kolejnych okresach programowania widać jednak coraz większy nacisk na tzw. triangulację w zakresie metod i źródeł danych wykorzystywanych w ewaluacji, czyli wykorzystanie różnych metod i danych w celu jak najbardziej szerokiego i kompleksowego spojrzenia na badane problemy i zjawiska.

\section{System oceny PROW 2007-2013}

PROW 2007-2013 był zbudowany w oparciu o podział instrumentów na cztery osie programowania. W ramach każdej osi zgrupowano działania służące realizacji celu wsparcia, do którego odnosiła się dana oś. Każde z działań miało dodatkowo sformułowane swoje cele szczegółowe, jednak stanowiły one tylko uzupełnienie celu podstawowego zdefiniowanego dla danej osi. Wyróżniono następujące osie:

- Oś 1. Poprawa konkurencyjności sektora rolnego i leśnego.

- Oś 2. Poprawa środowiska naturalnego i obszarów wiejskich.

- Oś 3. Jakość życia na obszarach wiejskich i różnicowanie gospodarki.

- Oś 4. Leader.

W okresie programowania 2007-2013 na etapie ewaluacji w połowie okresu programowania, jak i ewaluacji końcowej ważną rolę odgrywały pytania ewaluacyjne. Część z nich dotyczyła PROW 2007-2013 jako całości, zaś pozostałe odnosiły się do poszczególnych działań. Dla osi Leader sformułowano cztery odrębne pytania. Dla działań 


\section{B. Wieliczko}

osi 1-3 kluczowym pytaniem dla każdego z działań było pytanie o jego wpływ na realizację celu osi, którego dotyczyła dana oś. Jednocześnie jednak w przypadku tych działań każdorazowo należało odpowiedzieć na pytanie: Jakie inne efekty, w tym te odnoszące się do innych celów/osi, są powiązane $\mathrm{z}$ wdrażaniem danego działania (bezpośrednie pozytywne/negatywne efekty dotyczące beneficjentów, odnoszące się do pozostałych podmiotów, efekty na poziomie lokalnym)? (European Evaluation..., 2014). Równocześnie, uzupełniająco sformułowano również odrębne szczegółowe pytania do każdego z działań PROW 2007-2013. Dla przykładu dla działania 111. „Szkolenia zawodowe dla osób zatrudnionych w rolnictwie i leśnictwie" wyznaczono następujące pytania:

1. W jakim stopniu działania odnoszące się do szkoleń, informowania i dyfuzji wiedzy oraz innowacyjnych praktyk przyczyniły się do poprawy produktywności pracy i/lub innych elementów odnoszących się do konkurencyjności w sektorze rolnym, żywnościowym i leśnym?

2. W jakim stopniu szkolenia przyczyniły się do poprawy zrównoważonego zarządzania ziemią, w tym zrównoważonego zarządzania zasobami naturalnymi?

3. W jakim stopniu wsparte szkolenia były zgodne $\mathrm{z}$ potrzebami i spójne $\mathrm{z}$ innymi działaniami programu? (Directorate.... 2006)

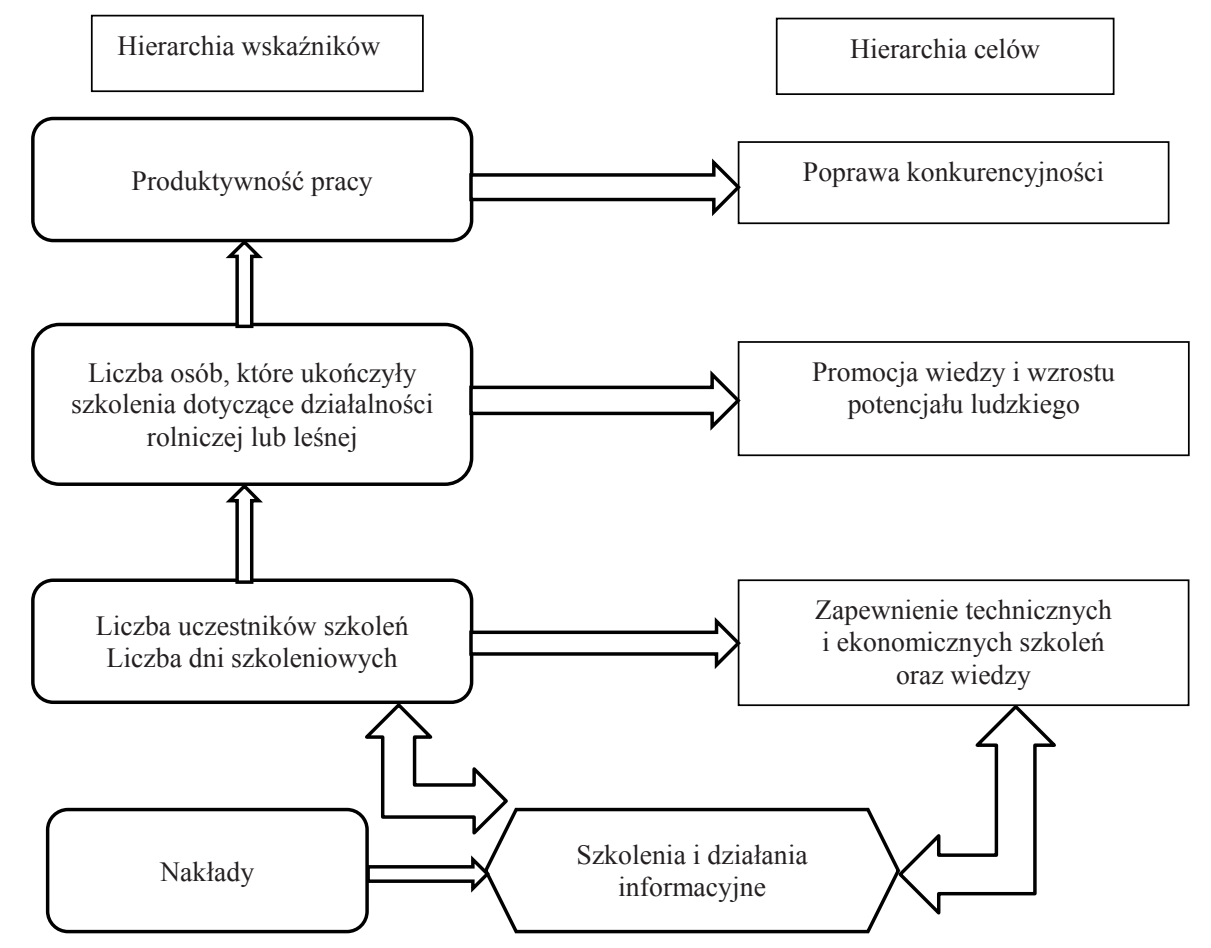

Rys. 1. Powiązanie między celami i wskaźnikami dotyczącymi działania 111. „Szkolenia zawodowe dla osób zatrudnionych w rolnictwie i leśnictwie"

Fig. 1. Links between aims and indicators in the case of Measure 111. "Vocational training and information actions"

Źródło: Directorate General for Agriculture and Rural Development (2006). 
Pytania ewaluacyjne powiązane były z kryteriami oceny oraz wskaźnikami, co miało sprzyjać ujednoliceniu podejścia do udzielania odpowiedzi na pytania ewaluacyjne. Bezpośrednie wskazanie na kryteria oceny oraz wskaźniki miało również zagwarantować kompleksowość odpowiedzi na te pytania. Szczególną uwagę zwrócono na analizę powiązań między hierarchią celów i hierarchią wskaźników (rys. 1), co miało uszczegółowić logikę interwencji oraz wskazać na wzajemne powiązania i zależności między rezultatami i oddziaływaniem wsparcia.

Należy dodać, że we wcześniejszym okresie programowania również wykorzystywano pytania ewaluacyjne oraz wskaźniki, jednakże w okresie programowania 2007-2013 rola wskaźników stosowanych w ocenie wzrosła. Ponadto wprowadzono wymóg, iż odpowiedzi na pytania ewaluacyjne muszą opierać się na danych, czemu dodatkowo miało sprzyjać powiązanie pytań z konkretnymi wskaźnikami (European Evaluation..., 2014).

\section{System oceny PROW 2014-2020}

W okresie programowania 2014-2020 priorytety zastapiły występujące w poprzednim okresie osie priorytetowe skupiające od kilku do kilku do kilkunastu działań. Wyznaczono sześć priorytetów, przy czym każdy program rozwoju obszarów wiejskich musiał być ukierunkowany przynajmniej na cztery z nich (Rozporządzenie nr 1305/2013). Jednocześnie każdemu z priorytetów przyporządkowano od trzech do pięciu celów szczegółowych. Priorytety polityki rozwoju obszarów wiejskich w okresie 2014-2020 to:

1. Wspieranie transferu wiedzy i innowacji w rolnictwie, leśnictwie i na obszarach wiejskich.

2. Zwiększenie rentowności gospodarstw i konkurencyjności wszystkich rodzajów rolnictwa we wszystkich regionach oraz promowanie innowacyjnych technologii w gospodarstwach i zrównoważonego zarządzania lasami.

3. Wspieranie organizacji łańcucha dostaw żywności, w tym przetwarzania i wprowadzania do obrotu produktów rolnych, promowanie dobrostanu zwierząt i zarządzania ryzykiem w rolnictwie.

4. Odtwarzanie, ochrona i wzbogacanie ekosystemów powiązanych z rolnictwem i leśnictwem.

5. Wspieranie efektywnego gospodarowania zasobami i przechodzenia na gospodarkę niskoemisyjną i odporną na zmianę klimatu w sektorach rolnym, spożywczym i leśnym.

6. Wspieranie włączenia społecznego, ograniczania ubóstwa i rozwoju gospodarczego na obszarach wiejskich (Rozporządzenie 1305/2013).

Punktem wyjścia do oceny śródokresowej oraz końcowej są wspólne pytania ewaluacyjne, których jest trzydzieści. Poszczególnym pytaniom towarzyszą kryteria oceny. Odpowiedzi na pytania powinny być oparte na wskaźnikach ewaluacyjnych. Pytania dotyczą poszczególnych celów PROW oraz takich kwestii, jak skala efektu synergii, znaczenie pomocy technicznej oraz roli PROW w realizacji celów strategii Europa 2020 i ogólnych celów WPR.

Każdemu z pytań dotyczących celów PROW przyporządkowano kryteria oceny, wspólne wskaźniki oraz dodatkowe informacje (European Evaluation..., 2015). Przykładem pytań dotyczących celów PROW jest pytanie odnoszące się do celu 3A, które brzmi następująco: W jakim stopniu interwencje w ramach PROW 2014-2020 przyczyniaja 


\section{B. Wieliczko}

się do poprawy konkurencyjności objętych wsparciem producentów rolnych poprzez lepsze ich zintegrowanie z łańcuchem rolno-spożywczym poprzez systemy jakości, dodawanie wartości do produktów rolnych, promocję na rynkach lokalnych i krótkie cykle dostaw, grupy producentów oraz organizacje międzybranżowe? Z pytaniem tym powiązano trzy kryteria oceny:

- Wzrost konkurencyjności producentów rolnych.

- Wzrost udziału rolników w cenie finalnej produktów rolnych.

- Wzrost wartości dodanej gospodarstw rolnych.

Określono jedynie jeden wspólny wskaźnik oceny, którym jest odsetek gospodarstw rolnych otrzymujących wsparcie $\mathrm{w}$ związku $\mathrm{z}$ uczestnictwem $\mathrm{w}$ systemach jakości, lokalnych rynkach i krótkich łańcuchach dostaw oraz grupach i organizacjach producentów. Wartość poznawcza tego wskaźnika wydaje się co najwyżej umiarkowana. Dla pełnego obrazu sytuacji należałoby znać kontekst, czyli zarówno skalę przeznaczonego na ten cel wsparcia, jak i odsetek rolników, który dzięki wcześniej stosowanym instrumentom wsparcia bądź bez jakiejkolwiek pomocy włączyli się w wyżej wymienione systemy.

Na potrzeby tego pytania określono również dodatkowe informacje, które mogłyby posłużyć udzieleniu odpowiedzi na pytanie ewaluacyjne. Objęły one: produkcję rolniczą wspieranych gospodarstw rolnych ${ }^{4}$, udział producentów rolnych w cenach finalnych produktów rolnych ${ }^{5}$ oraz odsetek rolników, którzy wdrażają systemy jakości w ramach wsparcia PROW. Faktycznie takie informacje pozwoliłyby na uzyskanie pełniejszej odpowiedzi na pytanie ewaluacyjne i powinny być szacowane przez ewaluatorów. Otwartym pytaniem pozostaje jednak kwestia sposobu szacowania tych wartości oraz sama możliwość uzyskania takich informacji w ramach istniejących systemów gromadzenia danych dotyczących beneficjentów wsparcia.

Szczególnie trudne i skomplikowane byłoby szacowanie udziału rolników w cenie finalnej produktów. Należałoby $\mathrm{w}$ istocie przeprowadzić kosztowne badanie na bazie studiów przypadku, co nawet przy ograniczeniu się do podstawowych produktów rolnych wymagałoby także znacznych nakładów czasu i nie zawsze dającej się zagwarantować współpracy ze strony beneficjentów wsparcia i jeszcze mniej pewnego współdziałania innych podmiotów (w tym wypadku przemysłu rolno-spożywczego i handlu). Wydaje się, iż koszt uzyskania niezbędnych danych mógłby w niektórych przypadkach przekraczać wysokość wsparcia, co stanowi argument za rezygnacją z szacowania zmiany w udziale rolnika w cenie produktów finalnych, bo to właśnie o wpływ wsparcia na udział rolnika $\mathrm{w}$ tej cenie chodzi w tym problemie badawczym.

Samo szacowanie udziału rolników w cenach produktów finalnych jest niezmiernie ważnym elementem oceny sytuacji rolnictwa i powinno być stale prowadzone, ale w związku ze złożonością rynku i olbrzymią liczbą zróżnicowanych produktów może dotyczyć jedynie wąskiej grupy najbardziej podstawowych produktów i może być realizowane jedynie w oparciu o system statystyki publicznej operujący w zupełnie innych strukturach organizacyjnych niż badania ewaluacyjne. Jednocześnie jednak wyniki takich badań prowadzonych w ramach statystyki publicznej nie dają się wprost przełożyć na problem oddziaływania wsparcia PROW na jego beneficjentów.

Od wielu lat eksperci zajmujący się ewaluacją polityki rozwoju obszarów wiejskich apelowali o zwiększenie jakości badań poprzez szersze i powszechniejsze stosowanie

\footnotetext{
${ }^{4}$ Nie wskazano, jak powinna być szacowana.

${ }^{5}$ Tutaj także brakuje szczegółowych wytycznych co do sposobu szacowania tego udziału.
} 
wskaźników. Miało to również zwiększyć porównywalność uzyskiwanych wyników. W obecnym okresie programowania dokonała się taka zmiana, ale jej rzeczywisty kształt $\mathrm{w}$ istocie stanowi karykature oczekiwanych rozwiązań. KE wprowadziła bardzo szczegółowy system raportowania wyników wdrażania PROW 2014-2020. System ten funkcjonujący jako aplikacja internetowa, w ramach której instytucja zarządzająca wypełnia odpowiednie pozycje. W niektórych wypadkach chodzi o wybranie jednej $\mathrm{z}$ wyświetlających się opcji, a w innych wymusza wpisanie określonej informacji w ściśle wyznaczonym formacie, np. liczby z dokładnością nie większą niż dwa miejsca po przecinku.

Rozwiązanie to $\mathrm{z}$ zasady powinno służyć ujednoliceniu kształtu i charakteru przekazywanych informacji. Jednakże w rzeczywistości, przy możliwości wprowadzania własnych kryteriów i wskaźników wcale nie daje gwarancji porównywalności danych. W związku z tym faktyczny cel wdrożenia ujednoliconego formularza oceny nie spełnia w pełni pokładanych w nim nadziei. Ponadto istnieje obawa, iż wprowadzone dane w postaci wartości poszczególnych wskaźników będą mechanicznie porównywane bez wgłębienia się $\mathrm{w}$ ewentualne różnice metodologiczne dotyczące sposobu wyliczenia poszczególnych wskaźników, a zwłaszcza źródeł, charakteru i zakresu danych wykorzystanych w szacunkach. Grozi to błędną interpretacją różnic pomiędzy państwami członkowskimi i ich regionami w skali oddziaływania wsparcia.

Nie mniej istotnym problemem obecnego systemu ewaluacji jest mechaniczne łączenie korzystających $\mathrm{z}$ danej formy wsparcia $\mathrm{w}$ ramach obecnego i poprzedniego PROW. W tym przypadku chodzi o działania w przypadku których zbliżony instrument był stosowany w ramach PROW 2007-2013, a beneficjenci kontynuują otrzymywanie rocznych płatności jeszcze z PROW 2014-2020. Takie łączenie obu grup może być nieuprawnione w związku z ewentualnymi zmianami w kryteriach dostępu czy/i wyboru wniosków. Naturalnie wpływ wsparcia PROW 2014-2020 powinien obejmować podmioty, którym przyznano wsparcie w ramach PROW 2007-2013 i nadal otrzymują wsparcie, gdyż to środki PROW 2014-2020 w istocie wpływają na funkcjonowanie tych podmiotów i uzyskiwane przez nie wyniki ekonomiczne. Jednakże z punktu widzenia rzetelności i przejrzystości badania konieczne jest oddzielanie obu grup beneficjentów.

Najważniejszym novum w systemie ewaluacji w obecnym okresie wydaje się jednak odejście od dotychczasowego podejścia do oceny w oparciu o działania PROW. Obecnie pytania ewaluacyjne nie dotyczą poszczególnych działań, lecz celów, a na realizacje poszczególnych celów może się składać kilka różnych typów działań czy poddziałań. To, które instrumenty odnoszą się do danego celu wyznacza logika interwencji przyjęta przez podmiot, który opracował dany PROW 2014-2020. W praktyce może to oznaczać to, że jeden instrument może służyć realizacji więcej niż jednego celu. Jest to oczywiście naturalne zważywszy na złożoność interwencji i wielokierunkowość ich oddziaływania. W praktyce jednak oznacza, iż na potrzeby więcej niż jednego pytania ewaluacyjnego analizowany jest ten sam instrument. Jest to znaczne utrudnienie dla zespołu prowadzącego ewaluację, gdyż w praktyce prowadzenia badania ewaluacyjnego, które jest bardzo ograniczone jeśli chodzi o długość okresu prowadzenia prac, osoby przypisane do poszczególnych pytań ewaluacyjnych muszą zgłębić zasady funkcjonowania kilku, często bardzo odmiennych typów wsparcia. Dla przykładu w ramach polskiego PROW 2014-2020 realizacji celu 3A, czyli poprawie konkurencyjności objętych wsparciem producentów rolnych poprzez lepsze ich zintegrowanie $\mathrm{z}$ łańcuchem rolno-spożywczym poprzez systemy jakości, dodawanie wartości do produktów rolnych, promocję na rynkach lokalnych 


\section{B. Wieliczko}

i krótkie cykle dostaw, grupy producentów oraz organizacje międzybranżowe, służą następujące typy operacji:

- Wsparcie kształcenia zawodowego i nabywania umiejętności.

- Wsparcie na demonstracje i działania informacyjne.

- Wsparcie dla nowych uczestników systemów jakości.

- Wsparcie na przeprowadzenie działań informacyjnych i promocyjnych.

- Przetwórstwo i marketing produktów rolnych.

- Inwestycje w targowiska lub obiekty budowlane przeznaczone na cele promocji lokalnych produktów.

- Tworzenie grup i organizacji producentów w sektorze rolnym i leśnym.

- Współpraca w ramach grup EPI.

Oczywiście może się okazać, że dany typ operacji w związku ze swoją specyfiką lub sposobem wyznaczenia kryteriów dostępu i kryteriów wyboru może być istotny dla realizacji jednego celu, a bardzo nieznaczący dla uzyskania innego z celów, którym miał służyć. Analizowanie poszczególnych typów wsparcia $\mathrm{w}$ ramach różnych celów $\mathrm{z}$ pewnością pozwala na wielostronną ich ocenę. Jednakże może prowadzić do sprzecznych wniosków i rekomendacji, co do ewentualnych zmian w stosowaniu danego instrumentu, co sugeruje zasadność dokonania na końcowym etapie ewaluacji analizy od strony działań, a nie pytań ewaluacyjnych. Nie jest to jednak przewidziane przez KE, a tym samym nie jest też wymagane przez zlecających badania ewaluacyjne.

\section{Podsumowanie}

Ocena programów rozwoju obszarów wiejskich jest szczególnie złożonym problemem z uwagi na zróżnicowanie stosowanych instrumentów i realizację ich na różnych poziomach przy udziale różnych typów aktorów (Yang i in., 2015). System wskaźników przyjęty w ramach oceny PROW 2007-2013 i rozwijany w obecnym okresie programowania jest nadal niewystarczające do pełnej oceny oddziaływania wsparcia. Chodzi nie tylko o same luki w danych, ale także o kwestię rozszerzania zakresu oceny o inne podejścia i elementy badania. Próba ograniczenia się do porównywania wskaźników będzie krzywdząca dla poszczególnych PROW, gdyż wskaźniki nie są w stanie pokazać pełnego tła realizacji programów oraz ich efektów. W związku z tym należy skoncentrować się na analizie tego, jakie efekty przynoszą poszczególne rozwiązania i wynikających $\mathrm{z}$ tego rekomendacjach w postaci dobrych praktyk na poziomie projektowania i wdrażania wsparcia.

W systemie oceny PROW 2014-2020 zaszly znaczące zmiany w porównaniu z poprzednim okresem programowania. W założeniu twórców tych zmian miały one na celu podniesienie jakości ewaluacji poprzez koncentrację na wskaźnikach i wykorzystaniu różnych źródeł danych. W istocie jednak samo włączenie większej liczby wskaźników nie przyczyni się do podniesienia przydatności ewaluacji do oceny wpływu wsparcia.

Problem istotności wskaźników dla jakości wyników badań ewaluacyjnych był już wyraźnie podkreślony w wytycznych dotyczących oceny PROW 2007-2013, a same wskaźniki były szczegółowo opisane i podzielone na kategorie od produktów poprzez

${ }^{6}$ Operacja to pojęcie podrzędne wobec poddziałania, co oznacza, iż na jedno poddziałanie może składać się więcej niż jeden typ operacji. 
rezultaty po oddziaływanie. W obecnym okresie podział ten, jak i większość wskaźników nie uległy zasadniczym zmianom. Położono jednak nacisk na ich rzeczywiste szacowanie i wykorzystywanie $\mathrm{w}$ ocenie. Nie zmienia to jednak problemu braku dostępności odpowiednich danych. Kluczowym problemem jest tu okres, jaki upływa między analizowanym rokiem a dostępem do danych dotyczacych tego roku. W związku z tym problemem wiele wskaźników jest wyznaczanych dla danych dotyczących tylko części okresu objętego oceną, co negatywnie wpływa na poziom oszacowanego oddziaływania wsparcia.

W rezultacie badania ewaluacyjne nie pokazują pełnej skali wpływu interwencji na sytuację wspartych podmiotów i ich otoczenie społeczno-gospodarcze i stają się swoista sztuką dla sztuki. Aby to zmienić należałoby przesunać termin wykonywania ewaluacji w kolejnym okresie programowania. W obecnym okresie ocenę śródokresową z góry ustalono na 2017 rok i miała ona obejmować okres 2014-2020. Rzeczywiście rok 2017 leży dokładnie w połowie okresu 2014-2020, ale w takim wyliczeniu nie uwzględniono dwóch kluczowych faktów: 1. Okres realizacji PROW 2014-2020 kończy się wraz z końcem 2023 r., a nie 2020 r.; 2. Z uwagi na opóźnienia w uruchamianiu PROW i jego poszczególnych instrumentów $\mathrm{w}$ wielu przypadkach pierwsi beneficjenci wsparcia nie pojawiają się w pierwszym roku okresu programowania, lecz znacznie później (nawet 3 lata później), co prowadzi do tego, że ewaluatorzy w przypadku zbyt wcześnie wyznaczonego terminu oceny śródokresowej nie mają w praktyce czego oceniać 7 .

Podsumowując, można stwierdzić, iż system oceny PROW 2014-2020 nie zapewnia większej wiedzy o efektach wsparcia w porównaniu z okresem programowania 2007-2013. Wręcz przeciwnie, można uznać, iż $\mathrm{w}$ związu $\mathrm{z}$ brakiem kompleksowej oceny poszczególnych działań i poddziałań traci się możliwość rzetelnej oceny przydatności każdego z zastosowanych instrumentów, gdyż ocena na poziomie celów wydaje się zbyt ogólna, co gorsza jest niezbyt przejrzysta dla decydentów i opinii publicznej. Ewaluacja na poziomie celów jest ważna z punktu widzenia celów strategicznych wsparcia, lecz nie daje się bezpośrednio zoperacjonalizować i być użyteczna do odpowiedzi na pytanie, które instrumenty powinny być wdrażane z punktu widzenia potrzeb rozwojowych obszarów wiejskich $\mathrm{w}$ danym państwie czy regionie.

Wydaje się, iż prace nad doskonaleniem systemu oceny kolejnych programów rozwoju obszarów wiejskich powinny dotyczyć nie tylko kwestii doboru wskaźników i metod ewaluacji, ale także możliwości przeniesienia wyników ewaluacji na konkretne rozwiązania dotyczące instrumentarium polityki rozwoju obszarów wiejskich UE.

\section{Literatura}

Bienias, S., Strzęboszewski, P., Opałka, E. (2012). Ewaluacja. Poradnik dla pracowników administracji publicznej (Evaluation. Guide for public administration employees). Warszawa, Ministerstwo Rozwoju Regionalnego. Directorate General for Agriculture and Rural Development (2006). Rural Development 2007-2013. Handbook on Common Monitoring and Evaluation Framework. Guidance document. Brussels: European Union.

Esposti, R., Sotte, F. (2013). Evaluating the effectiveness of agricultural and rural policies: an introduction. European Review of Agricultural Economics, 40(4), 535-539.

\footnotetext{
${ }^{7} \mathrm{~W}$ rezultacie oznacza to ponowienie oceny logiki interwencji i analizy powiązań między działaniami, na co wskazano np. autorzy raportu „Ocena rezultatów wdrażania Programu Rozwoju Obszarów Wiejskich na lata 2014-2020 w latach 2014-2016” (IERiGŻ-PIB, IUNG-PIB, 2017).
} 


\section{B. Wieliczko}

European Evaluation Helpdesk for Rural Development, European Commission (2014). Capturing the success of your RDP: Guidelines for the ex post evaluation of 2007-2013 RDPs. Brussels: European Union.

European Evaluation Helpdesk for Rural Development, European Commission (2015). Common evaluation questions for rural development programmes 2014-2020. Brussels: European Union.

European Evaluation Helpdesk for Rural Development, European Commission (2016). Guidelines assessment of RDP results: how to prepare for reporting on evaluation in 2017. Brussels: European Union.

Gorzelak, A., Herda-Kopańska, J., Kulawik, J., Soliwoda, M., Wieliczko, B. (2017). Kontrowersje wokół europejskiej wartości dodanej tworzonej przez WPR (Controversies over the European value added created by CAP). Zagadnienia Ekonomiki Rolnej, 1, 3-28.

Ocena rezultatów wdrażania Programu Rozwoju Obszarów Wiejskich na lata 2014-2020 w latach 2014-2016 (Evaluation of the results of the implementation of the Rural Development Programme 2014-2020 in the years 2014-2016) (2017). IERiGŻ-PIB, IUNG-PIB. Raport końcowy. Warszawa, MRiRW.

Midmore, P., Langstaff, L., Lowman, S., Vaughan A. (2008). Qualitative evaluation of European Rural Development Policy: Evidence from Comparative Case Studies. Selected paper prepared for presentation at 12th Congress of the European Association of Agricultural Economists - EAAE 2008.

Olejniczak, K. (2007). Teoretyczne podstawy ewaluacji ex-post (Theoretical basis of ex-post evaluation). W: A. Haber (red.) Ewaluacja ex-post. Teoria i praktyka badawcza (s. 15-42). Warszawa, PARP.

Prager, K., Nienaber, B., Neumann, B., Phillips, A. (2015). How should rural policy be evaluated if it aims to foster community involvement in environmental management? Journal of Rural Studies, 37, 120-131.

Rozporządzenie Parlamentu Europejskiego i Rady (UE) nr 1305/2013 z dnia 17 grudnia 2013 r. w sprawie wsparcia rozwoju obszarów wiejskich przez Europejski Fundusz Rolny na rzecz Rozwoju Obszarów Wiejskich (EFRROW) i uchylające rozporządzenie Rady (WE) nr 1698/2005 (Regulation (EU) No 1305/2013 of the European Parliament and of the Council of 17 December 2013 on support for rural development by the European Agricultural Fund for Rural Development (EAFRD) and repealing Council Regulation (EC) No 1698/2005), Dz.U. UE L. 347.

Rozporządzenie Rady (WE) nr 1698/2005 z dnia 20 września 2005 r. w sprawie wsparcia rozwoju obszarów wiejskich przez Europejski Fundusz Rolny na rzecz Rozwoju Obszarów Wiejskich (EFRROW) (Council Regulation (EC) No 1698/2005 of 20 September 2005 on support for rural development by the European Agricultural Fund for Rural Development (EAFRD), Dz.U. UE L 277.

Wakeford, R. (2010). Evaluation of Rural Development Requires Clarity on Expected Outcomes. EuroChoices 9 , $37-41$.

Wieliczko, B. (2010). System oceny polityki Unii Europejskiej wobec obszarów wiejskich a zasady dobrego rządzenia (The evaluation system of the European Union's policy towards rural areas vs. the principles of good governance). Studia i Monografie, 149. Warszawa: IERiGŻ-PIB.

Yang, A., Rounsevell, M., Haggett, C., Piorr, A., Wilson, R. (2015). The Use of Spatial Econometrics, Stakeholder Analysis and Qualitative Methodologies in the Evaluation of Rural Development Policy. Journal of Environmental Assessment Policy and Management, 17(2), 1550023.

Do cytowania / For citation:

Wieliczko B. (2018). System oceny wsparcia programów rozwoju obszarów wiejskich 2014-2020. Problemy Rolnictwa Światowego, 18(1), 309-318; DOI: 10.22630/PRS.2018.18.1.28

Wieliczko B. (2018). System of Evaluation of Rural Development Programmes 2014-2020 (in Polish). Problems of World Agriculture, 18(1), 309-318; DOI: 10.22630/PRS.2018.18.1.28 